\title{
KONTROVERSI KEDUDUKAN 'ASHABAH DALAM HUKUM WARIS ISLAM MENURUT MADZHAB SYI’AH ITSNA ‘ASY‘ARIYYAH
}

\author{
A. Hasyim Asy'ari \\ Peneliti CESRAS Bandung Jawa Bandung \\ E-mail: syim_asari@yahoo.co.id
}

\begin{abstract}
In Islamic inheritance law system, ulama agreed on the distribution of waris as an 'ashabah, especially among Sunni. However, it is different from the opinions of ulama among Syi'ah Itsna 'Asy'ariyyah which stated that 'ashabah is out part from the Islamic inheritance law system. In determining the law, ulama Syi'ah Itsna 'Asy'ariyyah refers to the Koran, Hadith, and the consensus of the ulama (ijma), and the thought by different ways and methodologies with Sunni. Ulama Syi'ah Itsna 'Asy'ariyyah has understood 'ashabah with their own understanding. They said that 'ashabah (the residual) is only given to a group of men from tirkah given to 'ashabah al-furudl, they thought that the residual must be returned to all thabaqat certain groups. Therefore, ulama Syi'ah Itsna 'Asy'ariyyah were denying the extance of 'ashabah In the Islamic inheritance law system. Based on the issue, this paper try to explain the understanding of ulama Syi'ah Itsna 'Asy'ariyyah in determining the law, especially in field of 'ashabah.
\end{abstract}

\begin{abstract}
Abstrak
Dalam sistem kewarisan Islam, ulama sepakat tentang adanya sistem pembagian harta waris secara 'ashabah, terutama dikalangan Sunni. Akan tetapi, hal ini berbeda dengan pendapat ulama dikalangan Syi'ah Itsna 'Asy'ariyyah yang menyatakan bahwa 'ashabah dalam sistem kewarisan Islam itu tidak ada. Dalam menetapkan hukum, Syi'ah Itsna 'Asy'ariyyah berpegang pada sumber hukum al-Quran, al-Hadits, ijma, dan akal dengan cara dan metodologi yang berbeda dengan Sunni. Ulama Syi'ah Itsna 'Asy'ariyyah memahami 'ashabah dengan pemahaman mereka sendiri, menurutnya 'ashabah (sisa) hanya diberikan kepada kelompok laki-laki dari tirkah yang diberikan kepada 'ashabah al-furûdl, karena menurutnya sisa yang ada harus dikembalikan kepada seluruh kelompok ahli waris dalam thabaqat tertentu. Oleh karenanya, Syi'ah Itsna 'Asy'ariyyah membatalkan adanya 'ashabah dalam sistem kewarisan Islam. Tulisan ini mencoba untuk menguraikan pemahaman Ulama Syi'ah Itsna 'Asy'ariyyah dalam menetapkan hukum Islam, khususnya dalam masalah 'ashabah.
\end{abstract}

Kata kunci:

'ashabah, Hukum Waris Islam, Syi'ah Itsna 'Asy‘ariyah

\section{A. Pendahuluan}

Agama Islam mengandung jalan hidup manusia yang paling sempurna dan memuat ajaran untuk menuntun umat manusia kepada kebahagiaan dan kesejahteraan. Dasar dan perundang-undangan Islam dapat diketahui melalui Al-Quran dan Sunnah. Hukum Islam yang mengandung serangkaian pengetahuan tentang aqidah, pokok akhlak dan perbuatan dapat dijumpai sumbernya yang asli dalam ayat-ayat Al-Quran.

Islam adalah pandangan hidup yang lengkap sebagai agama, etika, dan sistem hukum yang kesemuanya terpadu dalam satu ajaran yang menjangkau semua segi kehidupan masyarakat dan cabang kesusasteraan

'Muhammad Husayn Thabathaba'î, al-Mîzan fi Tafsîr al-Qur'ân (Beyrut: Dâr al-Kutub. 1987), hlm. 21. 
Islam. ${ }^{2}$ Semua hal tentang segi kehidupan manusia telah diatur dalam Al-Quran. Salah satu yang diatur dalam Islam adalah perputaran harta dan kepemilikan pada seluruh masyarakat. $^{3}$

Setiap orang akan berusaha untuk memperoleh kekayaan sehingga dapat memilikinya. Salah satu cara pemilikan harta yang telah ditetapkan syara' yaitu dengan cara pewarisan atau khâlafiyah. ${ }^{4}$

Hukum waris merupakan bagian dari hukum keluarga yang memegang peranan penting, bahkan menentukan dan mencerminkan sistem dan bentuk hukum yang berlaku di masyarakat. ${ }^{5}$ Hukum kewarisan dalam Islam merupakan bentuk hukum yang khusus mengatur peralihan harta seseorang yang telah meninggal dunia kepada orang yang masih hidup, karena di dalam hukum waris memuat peraturan-peraturan untuk mengatur proses harta benda dan barang-barang yang terwujud dari satu angkatan manusia kepada turunannya.

Kekayaan seseorang yang meninggal menurut hukum waris Islam dibagikan sedemikian rupa sehingga semua anak, isteri atau suami, ayah, ibu dan saudara (laki-laki maupun perempuan) sebagai keluarga terdekat mendapat bagian terdahulu. Demikian pula mengatur harta peninggalan dan cara menghitung bagian-bagiannya secara tepat. ${ }^{6}$

Hukum waris Islam mengenal adanya azas ijbari, yakni peralihan menurut kehendak Allah SWT, tanpa tergantung kehendak muwaris atau ahli waris. Hukumm waris Islam mengandung azas-azas yang dalam beberapa hal berlaku pula dalam hukum waris yang semata-mata bersumber kepada akal manusia. Selain itu hukum kewarisan Islam mempunyai corak tersendiri.

${ }^{2}$ J.N.D. Anderson, Hukum Islam di dunia modern (Surabaya: Amapress. 1990), hlm. 18.

${ }^{3}$ Abû al-A'la Al-Maududi, Dasar-dasar Islam (Bandung: Pustaka.1984), hlm. 135.

${ }^{4}$ Hasby Asy-Syidiqi, Pengantar Fiqh Muamalah (Bandung: Bulan Bintang. 1974), hlm. 9.

${ }^{5}$ Hazairin, Hadith kewarisan dan sistim bilateral (Jakarta: Tinta Mas.1964.), hlm. 11.

${ }^{6}$ Abdullah, Sosiologi Hukum Masyarakat (Jakarta: Rajawali Press. 1980.), hlm. 2.
Hal itu berbeda dengan kewarisan menurut hukum perdata (BW) yang peralihan hak kewarisannya tergantung kepada kehendak dan kerelaan ahli waris dan tidak berlaku dengan sendirinya.?

Keijbaran hukum waris Islam yang bersandarkan ayat-ayat Al-Quran dan Sunnah Nabi Muhammad SAW menyangkut proses peralihan harta warisan. Demikian pula mengenai dengan bagian-bagiannya telah ditentukan secara rinci.

Syi'ah merupakan salah satu golongan dalam Islam yang mempunyai beberapa perbedaan dengan golongan Sunni di banyak hal, baik dalam lapangan figh atau dalam lapangan yang lainnya.

Dalam hukum kewarisan Islam, Syi'ah mempunyai beberapa prinsip yang berbeda dengan kalangan Sunni. Diantara perbedaan itu adalah dalam masalah 'ashabah. Pada prinsipnya setiap ahli waris yang telah mempunyai sebab-sebab mempusakai, seperti adanya ikatan perkawinan, pertalian darah atau nasab, ikatan perwalian dalam pembebasan budak, dan telah memenuhi syaratsyarat untuk mempusakai, misalnya hidupnya orang mewarisi di saat kematian orang yang mewariskan, serta tidak terdapat salah satu dari penghalang-penghalang mempusakai adalah cakap untuk mempusakai.

Para ulama ahli farâ'id telah memberikan ta'rîf 'ashabah secara singkat, yaitu semua ahli waris yang mendapatkan semua harta pusaka apabila sendirian dan mengambil sisa pusaka setelah 'ashabah al-furûdl (ahli waris yang mendapat bagian tertentu) mengambil bagian mereka. ${ }^{8}$

Allah SWT telah berfirman dalam surat Al-Nisâ ayat 11 sebagai berikut:

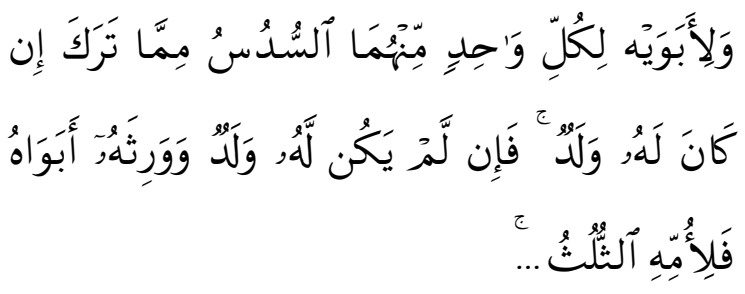

${ }^{7}$ A. Syarifuddin Al-Musawi, Isu-isu Penting Ikhtilaf Sunnah Syi'ah (Bandung: Mizan. 1984), hlm. 18.

${ }^{8}$ Fatcurrahman, Hukum Waris dalam Islam (Bandung: Al-Ma'arif. 1989), hlm. 221. 
Masing-masing ayah dan ibu mendapat bagian dari seperenam harta yang ditinggalkan apabila orang yang mati meninggalkan anak, apabila orang yang mati tidak meninggalkan anak maka ia (tirkah) diwarisi oleh bapak ibunya. Ibunya mendapat bagian sepertiga (sisanya untuk ayah). ${ }^{9}$

Muhammad Ali al-Shabûnî menafsirkan ayat ini bahwa bagian masing-masing ayah dan ibu apabila si mati meninggalkan anak, yaitu mendapat seperenam. Namun apabila orang yang mati tidak meninggalkan anak, maka harta pusaka untuk kedua orang tua. Al-Quran telah menyebutkan bagian ibu yakni sepertiga, tapi tidak disebutkan bagian ayah. Dengan demikian maka dapat ditarik kesimpulan yakni sisanya $2 / 3$ adalah bagian ayah dengan jalan 'ashabah. ${ }^{10}$

Kalangan Syi'ah yang dikemukakan oleh imam mereka yaitu Khamaynî dalam kitabnya Tahrîr al-Wasilah pada bagian tanbih bab waris, bahwa "ashabah itu dalam hukum kewarisan Islam tidak ada atau dibatalkan. ${ }^{11}$ Begitupula dalam kitab induk hadits mereka (Syi'ah) yaitu Wasâ'il al-Syi'ah pada bab tersendiri yang mengumpulkan hadits-hadits tentang itu yang terdiri dari 11 hadits. ${ }^{12}$

\section{B. Pengertian "ashabah}

Kata "“ashabah" pada mulanya dalam ba-hasa Arab diambil dari perkataan:

$$
\begin{aligned}
& \text { عصب القوم بالرجال إذا اجتمعوا واحاطوابه من اجل } \\
& \text { الحماية والدفاع }
\end{aligned}
$$

Kaum itu berkelompok dengan laki-laki, apabila mereka berkelompok dan bergaul dengannya, untuk saling jaga dan saling melindungi. $^{13}$

\footnotetext{
${ }^{9}$ A. Soenarjo, 1983, hlm. 116.

${ }^{10}$ Muhammad Ali al-ShAbûnî, Hukum Waris Dalam Islam (Bandung: Diponegoro. 1988.), hlm. 84.

${ }^{11}$ Khamayni, Tahrîru Al-Wasilah (Libanon: Dâr Al'Ilmu. t.th.), hlm. 377.

${ }^{12}$ Muhammad bin Hasan Al-Jurri, Wasâ'ilu Al-Syi'ah (t.pn.: Dâr Al-lhya Thurast Al-'Arabi. t.th), vol. VII, hlm. 431.

${ }^{13}$ Muhammad Ali al-Shabûnî, Hukum Waris. hlm.
}

Dalam Al-Quran kata "“ashabah" berarti golongan kuat, yaitu yang tertera dalam surat Yusuf ayat 14 sebagai berikut:

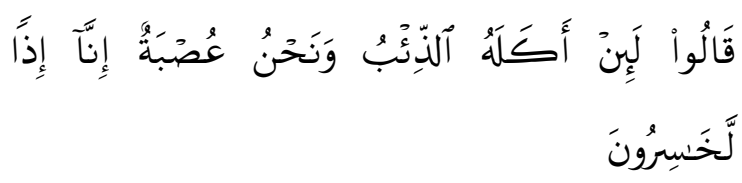

Mereka berkata: “Jika ia benar-benar dimakan serigala, sedangkan kami golongan (yang kuat), sesungguhnya kami kalau demikian adalah orang-orang yang merugi". ${ }^{14}$

Kata 'ashabah merupakan kalimat yang jama' mufradnya 'ashib. Proses menjadi jama'nya seperti kata thalabah jama' dari kata thâlib, kamalah jama' dari kata kâmil. AlAzhari berkata: 'ashabah adalah jama' yang tidak ada mufradnya, kemudian kalimat 'ashabah dipergunakan untuk seorang (satu orang), untuk jama' (banyak orang lebih dari dua), untuk laki-laki dan untuk perempuan. Adapun mashdar (pokok kata dari 'ashabah) ialah ushubah. ${ }^{15}$

Menurut Zakiyah Daradjat, bahwa pengertian 'ashabah secara bahasa adalah anak dari kerabat seseorang dari jihad ayah. ${ }^{16} \mathrm{Hal}$ ini sebagaimana pendapat Fatchurrahman mengartikan lafadz "ashabah hanya kerabat seseorang dari jurusan ayah. ${ }^{17}$ Hasbi menyebutkan bahwa ahli farâ'idh mengartikan kata 'ashabah dengan maksud kerabat dari pihak ayah yang mereka namakan 'ashabah nasabiyyah, yakni yang datang dari jihad hubungan darah dan kerabat. Selain itu kalimat 'ashabah dipergunakan kepada kekerabatan. Menurut hukum (qarabah hukûmiyyah), 'ashabah adalah yang datang dari jihad memerdekakan budak, yang dinamakannya 'ushubah sababiyah yaitu 'ushubah yang disebabkan oleh memerdekakan budak. Adapun makna ta'shîb ialah menjadikannya 'ashabah atau menjadikannya seseorang yang menjadikan 'ashabah.

\footnotetext{
${ }^{14}$ Soenarjo, 1989, hlm. 350.

${ }^{15}$ Hasbi Ash-Shieddiqqy, Pengantar ilmu. hlm. 166.

${ }^{16}$ Zakiyah Daradjat, Dasar-dasar Agama Islam : Buku Teksi PAl di PT (Bandung: Bulan Bintang. 1984.) hlm. 82.

${ }^{17}$ Fatcurrahman, Hukum Waris, hlm. 221.
} 
Secara istilah pengertian 'ashabah dalam terminologi ulama Sunni adalah semua ahli waris yang tidak mempunyai bagian tertentu dengan jelas dalam Al-Quran dan Al-Hadits. ${ }^{18}$ Atau ahli waris yang tidak mendapat bagian yang sudah dipastikan besar kecilnya yang telah disepakati oleh seluruh fuqaha dan yang belum disepakati oleh mereka. ${ }^{19}$

Pengertian 'ashabah dalam perspektif Syi'ah dapat dikatakan sulit untuk diketahui, hal ini disebabkan ulama Syi'ah tidak menyebutkan secara khusus apa yang dimaksud dengan 'ashabah dalam hukum kewarisan Islam. Istilah yang digunakan oleh ulama Syi'ah ada dua term, pertama 'ashabah dan kedua ta'shîb. Pada awal bab atau pada judul pembahasan semua ulama Syi'ah menggunakan term ta'shîb, sedangkan dalam pembahasannya sering menggunakan term 'ashabah.

Salah satu pengertian ta'shîb menurut Jamaluddîn disebutkan dalam kitabnya AlRawdlah sebagai berikut:

$$
\text { اعطاء فاضل التركة من اصحاب الفروض الى عصبة المية }
$$

Memberikan sisa tirkah dari ashabu al-furûdl kepada ashabah al-mayyit. ${ }^{20}$

Dari definisi di atas, ada tiga istilah yang perlu dijelaskan, yaitu tirkah, ashabu al-furûdl dan 'ashabah al-mayyit. Tirkah adalah harta yang ditinggalkan oleh yang meninggal dunia, sedangkan ashabu al-furûdl yaitu golongan yang sudah ditentukan secara pasti bagian yang harus diterima dari harta waris.

Untuk mengetahui apa yang dimaksud dengan 'ashabah al-mayyit, dapat merujuk kepada penjelasan Imam Khamayni dalam kitabnya Tahrir Al-Wasilah disebutkan bahwa ashabah al-mayyit sebagai berikut:

$$
\text { كل ذكر ينسب اليه بلا واسطه اوبوا سطة الذكور }
$$

Setiap laki-laki yang dinasabkan kepadanya tanpa perantara atau beberapa perantara laki-laki. $^{21}$

\footnotetext{
${ }^{18}$ Muhammad Ali Al-Shabûni, Hukum Waris. hlm.
} 82.

${ }^{19}$ Fatcurrahman, Hukum Waris, hlm. 339.

${ }^{20}$ Jamaluddîn Al-Makky Al-Amily, Al-Bahiyah fi Syarh Al-Lumath Al-Damsyiqy (Bayrut: Dâr al-Kutûb. t.th.), Jilid IX, hlm. 61.

${ }^{21}$ Khamayni, Tahrîr Al-Wasilah, hlm. 377.
Dari dua keterangan di atas, dapat tergambar apa yang dimaksud dengan 'ashabah dalam perspektif ulama Syi'ah. Dalam proses ta'shîb atau pemberian 'ashabah, yaitu pemberian kelebihan (sisa) dari 'ashabah al-mayyit kepada 'ashabah al-mayyit. Sedangkan 'ashabah al-mayyit adalah golongan nasab dari pihak laki-laki. Dengan demikian golongan ahli waris dari pihak perempuan tidak mendapat bagian 'ashabah, dalam istilah lain pemberian 'ashabah hanya terbatas pada golongan ahli waris dari pihak laki-laki.

Hasil penelitian Abû Zahrah dalam kitabnya Al-Mîrâts 'Inda Al-Ja'fariyyah, dikemukakan bahwa:

$$
\text { والعصبات عندهم اقرب رجل ذكر لايتوسط بينه وبين }
$$

'ashabah menurut ulama Syi'ah (mereka) adalah kerabat laki-laki yang tidak diperantarai oleh wanita antara dia dengan yang meninggal. $^{22}$

Selanjutnya Abû Zahrah membuat perbedaan antara 'ashabah dan dzaw al-arhâm menurut Syi'ah, yaitu sebagai berikut:

$$
\begin{aligned}
& \text { فالتفرقة قائمة بين العصبات وذوى الارحام من ناحية ان } \\
& \text { العصبات يدلون بالذكور دائما ولا يدلون بالاناث... }
\end{aligned}
$$

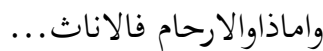

Perbedaan yang jelas antara 'ashabah dan dzawil arhâm dari esensinya bahwa 'ashabah itu selamanya tertuju pada laki-laki bukan untuk perempuan, sedangkan dzawil arhâm adalah untuk golongan perempuan. ${ }^{23}$

Dengan demikian, ini memperkuat bahwa ashabah menurut Syi'ah adalah hanya golongan laki-laki saja, bukan untuk golongan perempuan.

Selanjutnya Jamaluddîn menyebutkan satu perbandingan yang diharuskan oleh ulama Syi'ah dalam teknis pemberian sisa tersebut. Beliau menerangkan bahwa Syi'ah mewajibkan cara sebagai berikut:

$$
\text { راء الفاضل من التركة المى نفس من ورث اولا }
$$

${ }^{22}$ Abû Zahrah, Al-Mirats 'Inda Al-Ja'fariyyah (Beirut: Dâr al-Kutub. t.th.), hlm. 86.

${ }^{23}$ Abû Zahrah, Al-Mirats 'Inda. hlm. 82. 
Mengembalikan sisa (kelebihan) dari tirkah kepada jiwa perorangan yang diwarisi pada thabaqat pertamanya (yang lebih atas).

Untuk lebih memperjelas perkataan di atas, maka bisa dipahami terlebih dahulu alasannya sebagai berikut:

$$
\text { لانه لايعطى شيئ لاصحاب الطبقة التالية مع وجد من }
$$

Sebab itu maka tidak boleh memberikan sesuatu kepada golongan thabaqat yang berikutnya dalam keadaan ada salah seorang dari thabaqat yang lebih dekat.

Sebagaimana telah dijelaskan dalam pembahasan umum kewarisan Syi'ah bahwa dalam sistem pembagiannya ada pembagian menurut sistem thabaqat, dimana pada thabaqat pertama yaitu orang tua dan anak tidak bisa berkumpul satu kasus dengan thabaqat yang kedua dan ketiga, begitu pula thabaqat yang kedua tidak bisa berkumpul dengan thabaqat yang ketiga dalam satu kasus pewarisan.

Kembali kepada permasalahan di atas, bahwa yang diakui atau yang dibenarkan oleh ulama Syi'ah adalah pengembalian kelebihan kepada perorangan pada thabaqat yang lebih atas. Jadi tidak bisa sisa itu dikembalikan kepada thabaqat yang lebih bawahnya. Selain itu tidak bagi kelompok laki-laki saja, akan tetapi kepada seluruh ahli waris yang ada pada thabaqat yang berikutnya dan bersangkutan.

Lebih jelas lagi Imam Khamayni menyebutkan bahwa:

$$
\begin{aligned}
& \text { لو كانت التركة ازيد من السهام فترد الزيادة على ارباب } \\
& \text { الفروض ولاتعطى لعصبة الميت }
\end{aligned}
$$

Jika terbukti tirkah itu lebih dari sahamnya maka dikembalikan kelebihan itu kepada kelompok dari bagiannya dan juga diberikan kepada 'ashabah al-mayit. ${ }^{24}$

Hal yang senada diungkapkan oleh Amin Islam sebagai berikut:

$$
\begin{aligned}
& \text { القول بالعصبة يبطل عند نا ولا يورث بها فن موضع من }
\end{aligned}
$$

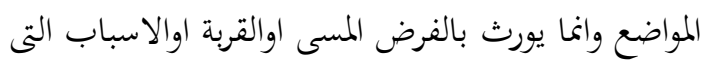

$$
\begin{aligned}
& \text { يورث بها }
\end{aligned}
$$

Bahwa pendapat tentang 'ashabah adalah batal menurut kami dan tidak mewarisi dengannya dalam satu tempat dari beberapa tempat, akan tetapi mewarisi dengan bagian tertentu, kerabat, dan oleh beberapa sebab.

\section{Kedudukan Hukum 'Ashabah dalam Ke- warisan Syi'ah}

Kedudukan hukum yang dimaksud dalam pembahasan ini adalah ada dan tidak adanya kelompok 'ashabah dalam hukum kewarisan Syi'ah serta bagaimana aplikasinya dalam beberapa kasus.

Imam Khamayni dalam kitabnya Tahrîr Al-Wasîlah membuat judul dengan vonis hukum secara jelas tentang kedudukan hukum 'ashabah yaitu dengan ungkapan:

$$
\text { التعصب والعول باطلان }
$$

Pemberian secara 'ashabah dan 'awl adalah batal. ${ }^{25}$

Begitu pula Muhammad bin Hasan AlHurrî menjelaskan kedudukan hukum 'ashabah dengan redaksi sebagai berikut: "Bab pembatalan pemberian secara 'ashabah.

Kedua pendapat di atas menggunakan term ta'shîb dalam menetapkan batalnya 'ashabah dalam bentuk kewarisan Islam.

Amin Islam menjelaskan kedudukan hukum 'ashabah sebagai berikut:

$$
\text { القول بالعصابة يبطل عندنا }
$$

Pendapat tentang 'ashabah adalah batal menurut kami (Syi’ah).

Jamaluddin membatalkan 'ashabah dengan redaksi sebagai berikut: "Tidak ada bagian harta warisan bagi kelompok 'ashabah menurut kami, dengan ukuran penambahan bagian dari saham kecuali dengan tidak adanya yang lebih dekat kerabatnya dari mereka". ${ }^{26}$

\footnotetext{
${ }^{25}$ Ibid. hlm. 377.

${ }^{26}$ Jamaluddin, t.th., hlm. 61.
}

\footnotetext{
${ }^{24}$ Khamayni, Tahriru Al-Wasilah, hlm. 377.
} 
Muhammad Bâqir Al-Majlisî dalam kitabnya Mir'at al-Uqûl membahas tentang pembatalan 'ashabah dengan dimasukkan kepada pembahasan farâ'idl. Beliau menjelaskan secara lengkap diuraikan sebagai berikut:

"Jika seseorang berkata: maka jika sisasisa itu untuk saudara perempuan sendirian dan bagi saudara perempuan dua atau lebih, maka penentuan bagi mereka adalah setengah dari dua pertiga. Hal itu semuanya adalah diperuntukkan bagi mereka dan dikembalikan kepada mereka dan ini menunjukkan bahwa apa-apa yang tersisa itu adalah bagi selain mereka yaitu 'ashabah. Dia berkata kepadanya, tidak ada 'ashabah dalam kitab Allah dan juga tidak ada dalam Sunnah Rasulullah SAW".

Untuk lebih mendalam tentang pembahasan kedudukan hukum 'ashabah dalam kewarisan Syi'ah maka dapat dilihat dalam beberapa kasus yang menurut ulama Sunni termasuk kepada 'ashabah. Contohnya sebagai berikut:

1. Maka bagi anak perempuan sendirian adalah setengah dengan cara fard (bagian tertentu) dan bagi kedua orang tua adalah dua per-enam (2/6) dengan cara fard pula dan sisanya dibagikan diantara semuanya dengan cara qarabah dengan menghitungkan kepada bagian-bagian mereka; ${ }^{27}$

2. Anak laki-laki begitu pula anak perempuan beserta adanya anak laki-laki mewarisi secara qarabah, begitu pula dengan bapak dengan syarat tidak ada anak bagi mayit, begitu pula kakak secara mutlak dengan syarat adanya laki-laki di dalam mereka; ${ }^{28}$

3. Jika berkumpul ahli waris yang secara fard dengan yang secara qarabah, maka bagikanlah bagian yang secara fard dahulu kemudian sisanya secara qarabah. Maka jika berkumpul kedua orang tua beserta dengan anak laki-laki maupun perempuan, harta waris itu diberikan ke-

\footnotetext{
${ }^{27}$ Jamaluddin, t.th., hlm. 46.

${ }^{28}$ Khamayni, Tahrîru Al-Wasilah, hlm. 378.
}

pada bapak dan ibu masing-masing satu per-enam (1/6). Jika ada yang menghalang, dan mendapat satu per-tiga (1/3), jika tidak ada yang menghalang secara fard dan sisanya diberikan bagi bapak secara qarabah; ${ }^{29}$

4. Contoh yang bersifat komparatif dengan Sunni dikemukakan oleh Amin Islam sebagai berikut: "Anak perempuan dan akan perempuan dari laki-laki dan bapak, maka bagian anak perempuan mendapat setengah, bapak mendapat satu perenam (1/6) dan sisanya dikembalikan kepada keduanya. Sedangkan menurut mereka (Sunni) bagiannya itu adalah untuk bapak satu per-enam (1/6), dan bagi dua anak perempuan dua pertiga (2/3) dan sisanya bagi bapak dengan jalan "ashabah. ${ }^{30}$

\section{Dasar Hukum Penetapan 'Ashabah}

Dalam menetapkan tidak adanya 'ashabah dalam hukum kewarisan Syi'ah, ulama Syi'ah bersandar kepada Al-Quran dan Hadits, adapun ayat Al-Quran yang dijadikan dalil tidak adanya 'ashabah adalah sebagai berikut:

Surat Al-Nisâ ayat 7, yang dikemukakan oleh Muhammad Bâqir Al-Majlisî dalam kitabnya Mir'at Al-Uqûl sebagai berikut:

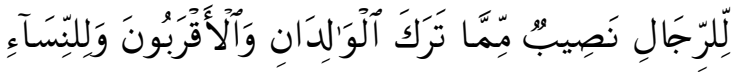

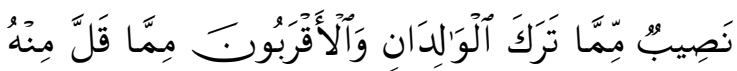

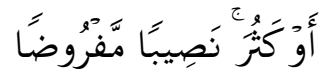

Bagi orang laki-laki ada hak bagian dari harta peninggalan ibu-bapa dan kerabatnya, dan bagi orang wanita ada hak bagian (pula) dari harta peninggalan ibu-bapa dan kerabatnya, baik sedikit atau banyak menurut bahagian yang telah ditetapkan. ${ }^{31}$

Surat Al-Anfâl ayat 75, sebagaimana dikemukakan oleh Jamaluddin, sebagai berikut:

\footnotetext{
${ }^{29}$ Ibid. hlm. 378.

${ }^{30} \mathrm{Amin}$ Al-Islam Fadli, Al-Mu'talif Min Al-Mukhtalif (Libanon: t.pn.. t.th), vol. II, hlm. 266.

${ }^{31}$ Soenarjo, 1989, hlm. 116.
} 


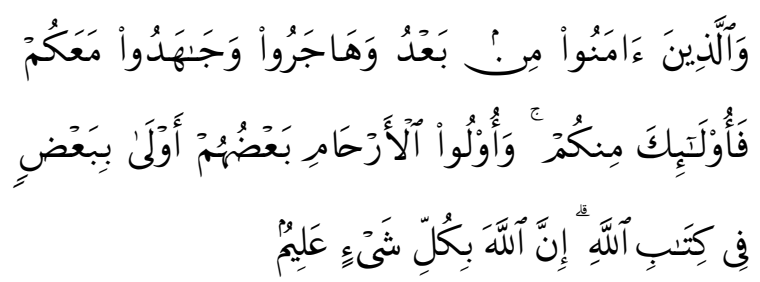

Dan orang-orang yang beriman sesudah itu kemudian berhijrah serta berjihad bersamamu Maka orang-orang itu Termasuk golonganmu (juga). orang-orang yang mempunyai hubungan Kerabat itu sebagiannya lebih berhak terhadap sesamanya (daripada yang bukan kerabat) di dalam kitab Allah. Sesungguhnya Allah Maha mengetahui segala sesuatu. ${ }^{32}$

Surat Al-Nisâ ayat 8 sebagai berikut:

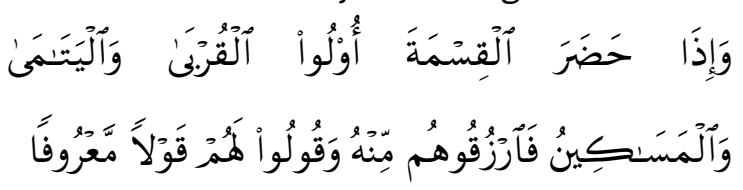

Dan apabila sewaktu pembagian itu hadir kerabat, anak yatim dan orang miskin, Maka berilah mereka dari harta itu (sekedarnya) dan ucapkanlah kepada mereka Perkataan yang baik. ${ }^{33}$

Ulama Syi'ah dalam menetapkan batalnya 'ashabah pada hukum kewarisan Islam selain menggunakan dasar hukum Al-Quran, mereka juga menggunakan dasar hukum dari Al-Hadits (dalam perspektif) Syi'ah. Adapun hadits-hadits yang dijadikan dalil oleh mereka adalah sebagai berikut:

1. Muhammad bin Ya'qub dari Ali bin Ibrahim dari Shalih bin Al-Sanâdy dari Ja'far bin Basyir dari Abdillah bin Baqir dari Husain Al-Ruzaz berkata: "Aku disuruh seseorang menanyakan kepada Abû Abdillah a.s. bahwa harta itu milik siapa? Ataukah untuk kerabat? Atau untuk 'ashabah? Maka dia menjawab bahwa harta itu milik karib kerabat dan 'ashabah dalam masalah ini seperti mulut yang tertutup dengan tanah (tercegah)";;34

\footnotetext{
${ }^{32}$ Soenarjo, 1989, hlm. 274.

${ }^{33}$ Soenarjo, 1989, hlm. 116.

${ }^{34}$ Muhammad bin Hasan Al-Jurri, Wasâilu AlSyi'ah, hlm. 431.
}

2. Muhammad bin Al-Hasan dengan sanadnya dari Shaffar dari Al-Sanâdy dari Musa bin Khunais dari pamannya Hasyim AlShaydany dari Abû Bakar bin 'lyasy dalam sebuah hadits bahwasannya dikatakan kepadanya: Apa yang diketahui dan diceritakan oleh Nuh bin Daraj dalam masalah hukum bahwa mewarisi saudara laki-laki dari ibu, menyingkirkan 'ashabah dan membatalkan syuf'ah, maka Abû Bakar bin lyasy berkata: mudahmudahan apa yang dikatakan pada lakilaki itu dihukumi dengan kitab dan sunnah, sesungguhnya Nabi Muhammad SAW, ketika gugurnya Hamzah bin Abdul Muthalib mengutus Ali bin Abi Thalib, kemudian Ali menemuinya SAW dengan putri Hamzah. Rasulullah SAW menyerahkan seluruh harta warisan kepada putri Hamzah tersebut; ${ }^{35}$

3. Dan daripadanya (Abi Thalib Al-Anbary) dari Al-Firyany dan dari Al-Shaghany seluruhnya, dari Abi Kuraib dari Ali bin Sa'id dari Ali bin Abbas dari Ibni Thowus dari bapaknya dari Ibni Abbas dari Nabi SAW bahwa beliau bersabda: "Bagikanlah harta warisan yang sudah ditentukan dan bagi yang tersisa maka lebih didahulukan kepada kelompok 'ashabah dari laki-laki”, dan dengan sanadnya dari Wahhyb dari Ibnu Thowus dan dari bapaknya sepertinya. Aku berkata bahwa tahu tentang hadits ini dari riwayat yang umum dan para ulama mengingkarinya dan hadits ini bertentangan dengan Al-Quran, dan membawanya kepada keadaan yang terhapus (mansûkh) dan dalam keadaan secara khusus dengan sebagian gambaran seperti pada waris diyat yang telah lalu; ${ }^{36}$

4. Dan dengan isnadnyaa dari Ali bin Hasan bin Fadldlal dari Abbas bin Amr dari Dawd bin Husayn dari Abi Abbas Fadlal Al-Baqbaq dari Abi Abdillah berkata, apakah bagi waitu itu siksa atau maaf? Dia berkata: "Tidak, dan itu adalah bagi "ashabah". Al-Syaikh berkata: Ali bin Hasan berkata, ini adalah masalah yang

\footnotetext{
${ }^{35}$ Ibid. hlm. 431-432.
}

${ }^{36}$ Ibid. hlm. 432. 
berbeda dengan kami. Aku berkata bahwa hal ini membawa pada keadaan taqiyyah; ${ }^{37}$

5. Muhammad bin Mas'ud Al-'lyyasyi dalam tafsirnya dari Ibnu Sunan dan dari Abi Abdillah a.s. berkata: Ali bin Abi Thalib dan Usman meninggalkan seorang laki-laki yang meninggal dan tidak mempunyai 'ashabah yang mewarisi dan baginya punya kerabat yang tidak mewarisi tidak ada bagian bagi mereka yang tertentu, maka berkata Ali a.s. ahli warisnya bagi yang mempunyai kerabatnya karena Allah SWT berfirman: "Dan ulul arham (yang mempunyai pertalian darah) sebagian lebih utama atas sebagian yang yang lainnya dalam kitab Allah". Usman berkata: "Jadikanlah harta itu untuk baitul mal milik muslimin". ${ }^{38}$

Amin Islam menanggapi atas pendapat Fuqaha Sunni yang bersandar kepada hadits sebagai berikut:

"Mereka menggunakan dalil dengan khabar yang diriwayatkan dari Ibnu Thawus dari bapaknya dari Ibnu Abbas dari Nabi Muhammad SAW, bahwasannya dia berkata: "Berikanlah bagian-bagian itu kepada ahlinya, maka sisa dari bagian ini untuk "ashabah laki-laki"."39

\section{E. Metode Penetapan Hukum dalam Me- netapkan Kedudukan 'Ashabah}

Dalam pembahasan pokok-pokok pikiran ulama Syi'ah, mereka dalam menetapkan hukum berpegang pada Al-Quran. Jika tidak terdapat dalam Al-Quran maka menggunakan Al-Hadits, selanjutnya ijma' dan terakhir dikenal sebagai lapangan ijtihadiyyah yaitu al-'aql. Dalam menetapkan kedudukan 'ashabah dalam kewarisan Islam, ulama Syi'ah menggunakan al-'aql yang intinya sebagai berikut:

1. Bahwa dalam Al-Quran dan Al-Hadits tidak ada penetapan adanya 'ashabah da-

\footnotetext{
${ }^{37}$ Ibid. hlm. 432-433.

${ }^{38} \mathrm{Ibid}$. hlm. 433.

${ }^{39} \mathrm{Amin}$ Al-Islam Fadli, Al-Mu'talif Min Al-Mukhtalif, hlm. 29.
}

lam hukum kewarisan Islam, dengan demikian tidak boleh membuat hal yang baru yang tidak ada dalam Al-Quran dan Al-Sunnah. Hal seperti itu diungkapkan oleh Muhammad Bâqir Al-Majlisî sebagai berikut: "Dalam kitab Allah (Al-Quran) dan di dalam Sunnah Rasul SAW (alHadits) tidak terdapat 'ashabah, akan tetapi Allah menceritakan dan menentukan demikian karena terkadang dikumpulkan saudara dari ibu dan berkumpulnya suami dan isteri. Penentuan ini menunjukkan bagaimana pembagiannya dan bagaimana menjadi kurang baginya, dan juga bagaimana hal itu menjadikan lebih baginya menurut ukuran sahamnya (bagian). Bagian-bagian itu jika ada mereka maka menurunkan dengan harta waris untuk selamanya dalam keadaan satu supaya amal dalam saham mereka seperti amal dalam saham anak menurut ukuran dikumpulkannya anak dari suami dan kedua orang tua, dan jika tidak sempurna maka tidak dapat menjadi petunjuk, oleh sebab itu Allah menjelaskannya dan hanya kepada Allah-lah kita meminta taufiq"; ${ }^{40}$

2. Jika "ashabah diberikan hanya kepada pihak laki-laki saja sebagaimana telah dikemukakan dalam definisi 'ashabah, maka menurut ulama Syi'ah jika 'ashabah adalah kelompok laki-laki hal itu dalam kenyataannya memang betul. Di kalangan Sunni, jika ahli waris perempuan sendirian tanpa ahli waris laki-laki maka tidak dapat menerima 'ashabah. Hal itu berarti dikalangan Sunni perempuan untuk mendapatkan 'ashabah harus dengan ahli waris laki-laki baik dalam 'ashabah bi al-nafsi maupun dalam 'ashabah bi al-ghayr. Pelaksanaan pembagian waris dengan adanya 'ashabah seperti dikemukakan di atas ditolak oleh oleh ulama Syi'ah dengan alasan bahwa ahli waris pihak laki-laki dan ahli waris pihak perempuan sama-sama mempunyai hak menerima harta warisan. Pemikiran ini merujuk kepada surat Al-Nisâ

${ }^{40}$ Muhammad Bâqir Al-Majlisî, Mir‘at Al-Uqûl (Libanon: t.pn. t.th.), vol. XXIII, hlm. 116. 
ayat 6 sebagaimana telah disebutkan dalam dasar hukum yang digunakan. Hal ini diungkapkan oleh Muhammad Baqir Al-Majlisy sebagai berikut: "Dan tidak berkata (Al-Quran) bahwa sisa itu adalah untuk laki-laki dan tidak bagi wanita, apa yang telah ditetapkan oleh Allah bagi laki-laki dalam satu keadaan maka diharamkan bagi perempuan, tetapi diwajibkan bagi wanita dalam sedikit atau banyak". ${ }^{41}$

Diakui pula oleh Abû Zahrah dalam penelitiannya terhadap hukum waris Syi'ah sebagai berikut: “Adapun fuqaha Syi'ah mereka telah menggambarkan kerabat wanita dalam cabangnya dan dalam kerabat yang semisalnya seperti kerabat laki-laki"; $4^{2}$

3. Dalam sistem kewarisan Islam menurut Sunni, harta waris itu bisa dibagikan secara fardl, 'ashabah dan dzawil arham, sedangkan dalam pandangan ulama Syi'ah harta waris itu dibagikan secara fardl, dan secara qarabah, hal tersebut seperti dikemukakan oleh Muhaqqiq AlHilly sebagai berikut: "Sebagian daripada mereka mewarisi dengan cara fardl dan yang lainnya dengan qarabah antara lain; bapak dan anak perempuan, anakanak perempuan dan saudari perempuan, saudari-saudari perempuan dan kalalah al-um, mereka itu mewarisi secara qarabah". ${ }^{43}$

Dalam penjelasannya Muhaqqiq Al-Hilly mengemukakan bahwa qarabah itu adalah ahli waris yang jumlah bagiannya tidak tentu. Berdasarkan pernyataan-pernyataan di atas dapat disimpulkan bahwa qarabah tidak terbatas hanya untuk laki-laki saja, tetapi perempuan pun berhak untuk mendapatkannya.

Imam Khamayni memberikan penjelasan kedua pembagian itu dalam bentuk aplikatif, yaitu sebagai berikut:

\footnotetext{
${ }^{41}$ lbid. hlm. 116.

${ }^{42}$ Abû Zahrah, al-Mîrats Inda, hlm. 97.

${ }^{43}$ Muhaqqiq Al-Hilly, al-Nasikh wa al-Mansûkh (t.t.:t.tpn. t.th.), hlm. 811.
}

"Jika berkumpul ahli waris yang fardl dengan yang qarabah, maka bagikan yang secara fardl kemudian sisanya dibagikan secara qarabah". ${ }^{44}$

Sesuai dengan pemikiran di atas, maka menurut Syi'ah tidak ada bagian harta warisan yang diterima secara 'ashabah, yang ada adalah pembagian secara fardl dan qarabah.

\section{F. Penutup}

Berdasarkan uraian di atas, maka dapat disimpulkan sebagai berikut:

1. Kedudukan 'ashabah dalam sistem kewarisan Syi'ah adalah tidak ada atau batal. 'ashabah dalam konsep pemikiran Syi'ah adalah pemberian sisa kelebihan tirkah dari golongan ashabu al-furudl kepada golongan ahli waris laki-laki. Dengan demikian, yang diperbolehkan adalah mengembalikan sisa tirkah dari ashabu al-furûdl kepada thabaqat yang lebih tinggi;

2. Dalam menetapkan kedudukan hukum 'ashabah, ulama Syi'ah Itsna 'Asyariyah menggunakan dasar hukum Al-Quran dan Al-Hadits. Adapun Al-Quran yang dijadikan dasar tersebut adalah surat AlAnfal ayat 75, Al-Nisâ ayat 7 dan 9. Sedangkan Al-Hadits yang digunakan dasar adalah hadits tentang 'ashabah yang dianggap sah oleh mereka (Syi'ah Itsna 'Asyariyah);

3. Metode penetapan hukum yang digunakan dalam menetapkan kedudukan hukum 'ashabah pada kewarisan Syi'ah meliputi:

a. Penalaran secara deduktif terhadap surat Al-Nisâ ayat 6. Penalaran deduktif tersebut bertolak dari premis bahwa sesuatu yang tidak ada hukumnya dalam Al-Quran hendaklah tidak di adakan. 'ashabah tidak terdapat dalam AlQuran, maka 'ashabah hukumnya adalah batal.

b. Pemahaman secara dhahir terhadap Al-Hadits (qaul al-ma'shum) yang secara langsung menerangkan pembatalan 'ashabah.

\footnotetext{
${ }^{44}$ Khamayni, Tahrîr Al-Wasilah, hlm. 378.
} 


\section{Daftar Pustaka}

Abdullah. 1980. Sosiologi Hukum Masyarakat. Jakarta: Rajawali Press.

Anderson, J.N.D. 1990. Hukum Islam di dunia modern. Surabaya: Amapress.

Asy-Syidiqi, Hasby. 1974. Pengantar Fiqh Muamalah. Bandung: Bulan Bintang.

Daradjat, Zakiyah. 1984. Dasar-dasar Agama Islam: Buku Teksi PAl di PT. Bandung: Bulan Bintang.

Fadli, Amin Al-Islam. t.th. Al-Mu'talif Min AlMukhtalif. Beirut Libanon: t.pn.

Fatcurrahman. 1989. Hukum Waris dalam Islam. Bandung: Al-Ma'arif.

Hazairin, Hadith kewarisan dan sistim bilateral. Jakarta: Tinta Mas.

Hilly, Muhaqqiq, al-. t.th. al-Nasikh wa I-Mansukh. t.t.: t.tp.
Jurri, Muhammad bin Hasan, al-. t.th. Wasâ'ilu Al-Syi'ah. t.pn.: Dâr Al-Ihya Thurast Al-Arabi.

Khamayni. t.th. Tahrîru Al-Wasilah. Beirut Libanon: Dâr Al-IImu.

Majlisy, Muhammad Baqir, al-. t.th. Mir'atul Al-Uqul. Beirut Libanon: t.pn.

Maududi, Abû al-A'la, al-. 1984. Dasar-dasar Islam. Bandung: Pustaka.

Musawi, A. Syarifuddin, al-. 1984. Isu-isu Penting Ikhtilaf Sunnah Syi'ah. Bandung: Mizan.

Shabûnî, Muhammad Ali, al-. 1988. Hukum Waris Dalam Islam. Bandung: Diponegoro

Thabathaba'î, Muhammad Husayn. 1987. Islam Syi'ah (Asal Usul Perkembangan Syiah). Jakarta: Pustaka Utama Grafiti.

Zahrah, Abû. t.th. Al-Mirats 'Inda Al-Ja'fariyah. Beyrut: Dâr al-Kutub. 